\title{
Composition, antioxidant and chemotherapeutic properties of the essential oils from two Origanum species growing in Pakistan
}

\author{
Abdullah I. Hussain, ${ }^{1,2}$ Farooq Anwar, ${ }^{2}$ Shazia Rasheed, ${ }^{3}$ Poonam \\ S. Nigam, ${ }^{3}$ Omar Janneh, ${ }^{4}$ Satyajit D. Sarker ${ }^{*, 5}$
}

${ }^{1}$ Department of Chemistry, GC University, Pakistan,

${ }^{2}$ School of Biomedical Sciences, University of Ulster, UK,

${ }^{3}$ Department of Chemistry and Biochemistry, University of Agriculture, Pakistan,

${ }^{4}$ Department of Biomolecular and Sport Sciences, Coventry University, UK,

${ }^{5}$ Department of Pharmacy, School of Applied Sciences, University of Wolverhampton, $U K$.

\begin{abstract}
The GC-MS analyses of Origanum majorana L. (OME) and Origanum vulgare L. (OVE), Lamiaceae, essential oils helped identification of 39 (96.4\% of the total oils) and 43 (92.9\% of the total oils) components, respectively. The major constituents of OME were terpinene-4-ol (20.9\%), linalool (15.7\%), linalyl-acetate (13.9\%), limonene (13.4\%) and $\alpha$-terpineol (8.57\%), whereas, thymol $(21.6 \%)$, carvacrol $(18.8 \%)$, o-cymene $(13.5 \%)$ and $\alpha$-terpineol $(8.57 \%)$ were the main components of OVE. In the disc diffusion and the resazurin microtitre assays, OME showed better antibacterial activity than OVE with larger zones of inhibition (16.5$27.0 \mathrm{~mm})$ and smaller MIC $(40.9-1250.3 \mu \mathrm{g} / \mathrm{mL})$ against the tested bacterial strains. Only OVE displayed anti-heme biocrystallization activity with an IC50 at 0.04 $\mathrm{mg} / \mathrm{mL}$. In the DPPH assay, OVE showed better radical-scavenging activity than OME (IC50 $=65.5$ versus $89.2 \mu \mathrm{g} / \mathrm{mL}$ ) and both OME and OVE inhibited lionleic acid oxidation. However, in the bleaching $\beta$-carotene assay, OVE exhibited better antioxidant activity than OME. In the MTT assay, OME was more cytotoxic than OVE against different cancer cell types, such as MCF-7, LNCaP and NIH-3T3, with IC50s of $70.0,85.3$ and $300.5 \mu \mathrm{g} / \mathrm{mL}$, respectively. Overall, some components of OME and OVE may have antiparasitic and chemotherapeutic activity.
\end{abstract}

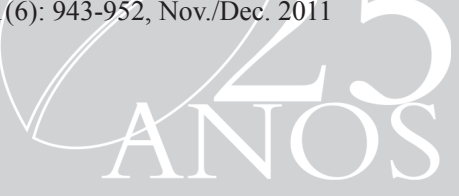

Article

Received 18 Oct 2010

Accepted 27 Dec 2010

Available online 9 Sep 2011

\section{Introduction}

The genus Origanum L., Lamiaceae, comprises ca. 38 species of annual, perennial and shrubby herbs, most of which are native to or restricted to the eastern part of the Mediterranean area, Europe, Asia and North Africa (GRIN Taxonomy Database, 2010). This genus includes some important culinary herbs and medicinal plants, including Origanum vulgare L. (common name 'oregano') and Origanum majorana L. (common name 'sweet marjoram'). The antioxidant and other biological properties of the Origanum essential oils and extracts have recently been of great interest in both academia and food industries because of their antioxidant and antimicrobial potentials. Even though a few reports on the antimicrobial and antioxidant activities of the Origanum essential oils are available to date (Daferera et al., 2000; Esen et al., 2007; Busatta et al., 2008), the potential antimalarial activity of $O$. vulgare and $O$. majorana essential oils have never been investigated before. In continuation of our phytochemical and bioactivity studies on plants of Pakistani flora (Anwar et al., 2009), we now report on the potential antibacterial, antimalarial, antioxidant activities and cytotoxicities of the essential oils of $O$. vulgare and O. majorana using various in vitro assays. Composition of these essential oils determined by GC and GC-MS has also been reported here.

\section{Material and Methods}

\section{Plant material}

The aerial parts of cultivated Origanum majorana L. and Origanum vulgare L. (Lamiaceae) at the flowering stage were harvested in July-August 2008 from the Botanical Garden, University of Agriculture, Faisalabad, Pakistan. The plant specimens were further 
identified and authenticated by Dr Mansoor Hameed (Taxonomist), Department of Botany, University of Agriculture, Faisalabad, Pakistan, where the voucher specimens (O. majorana voucher no. 10473 and $O$. vulgare voucher no. 10476) were deposited. The plant materials were dried at the temperature not exceeding $35{ }^{\circ} \mathrm{C}$ for essential oil isolation.

\section{Extraction of essential oils}

The dried and finely ground ( 80 mesh) plant materials were subjected to hydro-distillation for $3 \mathrm{~h}$ using a Clevenger-type apparatus (Hussain et al., 2008). Distillates of essential oils were dried over anhydrous sodium sulfate (Merck, Darmstadt, Germany), filtered and stored at $-4{ }^{\circ} \mathrm{C}$ until analyzed.

\section{Gas chromatography (GC) analysis}

The essential oils were analyzed using a PerkinElmer gas chromatograph model 8700, comprising flame ionization detector (FID) and HP-5MS capillary column (30 m x $0.25 \mathrm{~mm}$, film thickness $0.25 \mu \mathrm{m})$. The injector and detector temperatures were set at 220 and $290{ }^{\circ} \mathrm{C}$, respectively. The column oven temperature was programmed from $80{ }^{\circ} \mathrm{C}$ to $220^{\circ} \mathrm{C}$ at the rate of $4{ }^{\circ} \mathrm{C} / \mathrm{min}$; initial and final temperatures were held for 3 and $10 \mathrm{~min}$, respectively. Helium was used as carrier gas with a flow of $1.5 \mathrm{~mL} / \mathrm{min}$. A sample of $1.0 \mu \mathrm{L}$ was injected, using the slit mode (split ratio, 1:100). All quantifications were done by a built-in data-handling program of the equipment used (Perkin-Elmer, Norwalk, CT, USA). The composition was reported as a relative percentage of the total peak area.

Gas chromatography-mass spectrometry (GC-MS) analysis

The GC-MS analysis of the essential oils was performed on an Agilent-Technologies (Little Falls, California, USA) $6890 \mathrm{~N}$ Network gas chromatographic (GC) system, equipped with an Agilent-Technologies 5975 inert XL Mass selective detector and AgilentTechnologies 7683B series auto-injector. Compounds were separated on HP-5 MS capillary column (30 m x $0.25 \mathrm{~mm}$, film thickness $0.25 \mu \mathrm{m}$; Little Falls, CA, USA). A sample of $1.0 \mu \mathrm{L}$ was injected in the split mode with split ratio 1:100. For GC/MS detection, an electron ionization system, with ionization energy of $70 \mathrm{eV}$, was used. The column oven temperature program was the same as in the GC analysis. Helium was used as a carrier gas at a flow rate of $1.5 \mathrm{~mL} / \mathrm{min}$. Mass scanning range was $50-550 \mathrm{~m} / z$ while the injector and MS transfer line temperatures were set at 220 and $290{ }^{\circ} \mathrm{C}$, respectively.

\section{Identification of compounds}

The components of the essential oils were identified by comparison of their retention indices relative to $\left(\mathrm{C}_{9}-\mathrm{C}_{24}\right) n$-alkanes either with those of published data or with authentic compounds (Massada, 1976; Adams, 2004). Compounds were further identified using their MS data compared with those from the NIST02.L and WILEY7n.L mass spectral libraries and published mass spectra and, wherever possible, by coinjection with authentic standards (Mimica-Dukic et al., 2003; Vagionas et al., 2007; Anwar et al., 2009).

\section{Antibacterial assays}

The essential oils of $O$. majorana and $O$. vulgare were individually tested against a panel of pathogenic and clinically isolated bacterial strains, including: Staphylococcus aureus NCTC 6571, Bacillus cereus NCTC 7464, B. subtilis NCTC 10400, Pseudomonas aeruginosa NCTC 1662, Salmonella poona NCTC 4840, Escherichia coli ATCC 8739 and ampicillin-resistant $E$. coli NCTC 10418. The bacterial strains were obtained from Northern Ireland Public Health Laboratory, Belfast City Hospital, Belfast, and Microbiology Laboratory, School of Biomedical Sciences, University of Ulster, Coleraine, Northern Ireland, UK.

\section{Disc diffusion assay}

The antibacterial activity of the essential oils was assessed by the disc diffusion method (Kelen \& Tepe, 2008). Briefly, $100 \mu \mathrm{L}$ of suspension containing approx $5 \times 10^{5}$ colony-forming units $(\mathrm{CFU}) / \mathrm{mL}$ of bacteria cells on nutrient agar was used. The sterile filter discs $(6 \mathrm{~mm}$ in diameter $)$ were separately impregnated with $10 \mu \mathrm{L}$ of essential oils and placed on the agar which had previously been inoculated with the test microorganism. Ciprofloxacin $(25 \mu \mathrm{g} / \mathrm{disc})$ was used as positive control, while discs without oil were used as a negative control. The plates were incubated at $37{ }^{\circ} \mathrm{C}$ for $24 \mathrm{~h}$. Antibacterial activity was assessed by measuring the diameter of the zone of inhibition in millimeters (including disc diameter of $6 \mathrm{~mm}$ ) for the test organisms, compared to the controls.

\section{Resazurin microtitre-plate assay}

For the measurement of minimum inhibitory concentration (MIC) of essential oils of O. majorana and $O$. vulgare, a modified resazurin microtitre-plate assay, as reported by Sarker et al. (2007), was used. Briefly, a volume of $100 \mu \mathrm{L}$ essential oils solutions (2.5 $\mathrm{mg} / \mathrm{mL}, \mathrm{w} / \mathrm{v}$ in $10 \% \mathrm{DMSO})$, pure components $(2.0 \mathrm{mg} /$ 
$\mathrm{mL}$ in $10 \%$ DMSO $)$ and standard antibiotic $(1.0 \mathrm{mg} / \mathrm{mL}$ in $10 \%$ DMSO) was pipetted into the first row of the 96 well plates. To all other wells $50 \mu \mathrm{L}$ of nutrient broth was added. Two fold serial dilutions were performed using a multichannel pipette such that each well had $50 \mu \mathrm{L}$ of the test material in serially descending concentrations. A volume of $30 \mu \mathrm{L}$ of $3.3 \mathrm{x}$ strength isosensitized broth and $10 \mu \mathrm{L}$ of resazurin indicator solution (prepared by dissolving $270 \mathrm{mg}$ tablet in $40 \mathrm{~mL}$ of sterile distilled water) were added in each well. Finally, $10 \mu \mathrm{L}$ of bacterial suspension was added to each well to achieve a concentration of approx $5 \times 105 \mathrm{CFU} / \mathrm{mL}$. Each plate was wrapped loosely with cling film to ensure that bacteria did not become dehydrated. Each plate had a set of controls: a column with a ciprofloxacin as positive control, a column with all solutions with the exception of the test compound, a column with all solutions with the exception of the bacterial solution adding $10 \mu \mathrm{L}$ of nutrient broth instead and a column with $10 \%$ DMSO $(\mathrm{v} / \mathrm{v})$ solution as a negative control. The plates were prepared in triplicate, and incubated at $37{ }^{\circ} \mathrm{C}$ for 24 h. The color change was then assessed visually. The growth was indicated by color changes from purple to pink or colorless. The lowest concentration at which color change occurred was taken as the MIC value.

\section{Heme biocrystallization and inhibition assay for potential antimalarial activity}

The potential antimalarial activity of plant extracts was evaluated by the method described by Fitch et al. (1999) with some modifications (Tripathi et al., 2004). Briefly, $100 \mu \mathrm{L}$ of essential oils at a concentration of $0.01-10 \mathrm{mg} / \mathrm{mL}$ in $10 \%$ DMSO were incubated with $100 \mu \mathrm{L}$ of $3 \mathrm{mM}$ hematin (freshly dissolved in $0.1 \mathrm{M} \mathrm{NaOH}), 10 \mathrm{mM}$ oleic acid, $10 \mu \mathrm{L}$ of $1 \mathrm{M} \mathrm{HCl}$. After adding the test samples at varying concentrations, the reaction volume was adjusted to $1000 \mu \mathrm{L}$ using $500 \mathrm{mM}$ sodium acetate buffer of $\mathrm{pH} 5$. Chloroquine diphosphate was used as a positive control with the negative control containing buffer without test compounds. The samples were incubated for $4 \mathrm{~h}$ with gradual shaking/inverting of each tube. After incubation, samples were centrifuged $(14,000 \mathrm{rpm}, 10$ $\min$, at $21^{\circ} \mathrm{C}$ ) and the hemozoin pellets were repeatedly washed with $2 \%(\mathrm{w} / \mathrm{v})$ sodium dodecyl sulfate (SDS) in $0.1 \mathrm{M}$ sodium bicarbonate, $\mathrm{pH} 9.0$, with sonication (30 min, at $21^{\circ} \mathrm{C}$; FS 100 bath sonicator; Decon Ultrasonics Ltd.) until the supernatant was clear (usually 3-5 times). After the final wash, the supernatant was removed and the pellets were re-suspended in $1 \mathrm{~mL}$ of $0.1 \mathrm{M} \mathrm{NaOH}$ and incubated for an additional hour at r.t. Thereafter, the samples were vortexed and the hemozoin content was determined by measuring the absorbance at 400 nm (Beckmann DU640 spectrophotometer) using a 1 $\mathrm{cm}$ quartz cuvette. The concentration of drug required to produce $50 \%$ inhibition of polymerization (IC50) was determined graphically (Baelmans et al., 2000).

\section{Antioxidant activity}

The following assays were employed to assess the antioxidant properties of the essential oils.

\section{The DPPH radical scavenging assay}

The free radical scavenging activity of the Origanum essential oils was assessed by measuring their ability to scavenge 2,2'-diphenyl-1-picrylhydrazyl stable radicals (DPPH). The DPPH assay was performed as described by Mimica-Dukic et al. (2003). The samples (from 0.5 to $500.0 \mu \mathrm{g} / \mathrm{mL}$ ) were mixed with $1 \mathrm{~mL}$ of 90 $\mu \mathrm{M}$ DPPH solution and made up with $95 \%$ methanol, to a final volume of $4 \mathrm{~mL}$. Synthetic antioxidant, butylated hydroxytoluene (BHT) was used as control. After $1 \mathrm{~h}$ incubation period at room temperature, the absorbance was recorded at $515 \mathrm{~nm}$. Percent radical scavenging concentration was calculated using the following formula:

$$
\text { Radical scavenging }(\%)=100 \times\left(\mathrm{A}_{\text {blank }}-\mathrm{A}_{\text {sample }} / \mathrm{A}_{\text {blank }}\right)
$$

where $\mathrm{A}_{\text {blank }}$ is the absorbance of the control (containing all reagents except the test essential oils), and $A_{\text {sample }}$ is the absorbance of the test essential oils/compounds. IC50 values, which represented the concentration of essential oil that caused $50 \%$ scavenging, were calculated from the plot of percent scavenging against concentration.

\section{Percent inhibition in linoleic acid system}

The antioxidant activity was also determined in terms of measurement of percent inhibition of peroxidation in linoleic acid system following the method described by Iqbal et al. (2005) with slight modification. Essential oils (5 mg) were added to a solution mixture of linoleic acid $(0.13 \mathrm{~mL}), 99.8 \%$ ethanol $(10 \mathrm{~mL})$ and $10 \mathrm{~mL}$ of $0.2 \mathrm{M}$ sodium phosphate buffer ( $\mathrm{pH} 7$ ). Total mixture was diluted to $25 \mathrm{~mL}$ with distilled water. The solution was incubated at $40{ }^{\circ} \mathrm{C}$ for $175 \mathrm{~h}$. The extent of oxidation was measured by peroxide value using the colorimetric method. To the $0.2 \mathrm{~mL}$ sample solution, $10 \mathrm{~mL}$ of ethanol $(75 \%), 0.2$ $\mathrm{mL}$ of an aqueous solution of ammonium thiocyanate (30\%) and $0.2 \mathrm{~mL}$ of ferrous chloride solution $(20 \mathrm{mM}$ in $3.5 \% \mathrm{HCl}$ ) were added sequentially. After $3 \mathrm{~min}$ of stirring, the absorbance was read at $500 \mathrm{~nm}$. A control was performed with linoleic acid but without essential oils. BHT was used as a positive control. Percent 
inhibition of linoleic acid oxidation was calculated as follows:

Percent inhibition of linoleic acid oxidation $=100-$ [(increase in absorbance of sample at $175 \mathrm{~h} /$ increase in absorbance of control at $175 \mathrm{~h}$ ) $\mathrm{x} 100]$

Bleachability of $\beta$-carotene in linoleic acid system

The antioxidant activity of the essential oils was further assessed by the bleaching of $\beta$-carotene/ linoleic acid emulsion system as reported by Hussain et al. (2008). A stock solution of $\beta$-carotene-linoleic acid mixture was prepared by dissolving $0.1 \mathrm{mg} \beta$-carotene, $20 \mathrm{mg}$ linoleic acid and $100 \mathrm{mg}$ Tween 40 in $1.0 \mathrm{~mL}$ of chloroform (HPLC grade). The chloroform was removed under vacuum in a rotary evaporator at $50{ }^{\circ} \mathrm{C}$. Then, $50 \mathrm{~mL}$ of distilled water saturated with oxygen

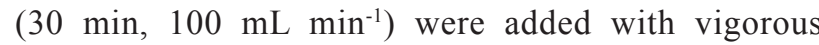
shaking. An aliquot $(5.0 \mathrm{~mL})$ of this reaction mixture was dispensed to test tubes with $200 \mu \mathrm{L}$ of the essential oils or main components solution, prepared at $4.0 \mathrm{~g} / \mathrm{L}$ concentrations and the absorbance immediately ( $t$ $=0$ ) measured at $490 \mathrm{~nm}$ against a blank, consisting of an emulsion without $\beta$-carotene. Then emulsion was incubated for $50 \mathrm{~h}$ at room temperature and the absorbance recorded at different time intervals. The same procedure was repeated with BHT and blank.

\section{Anticancer assay: cytotoxicity}

The human breast cancer cell line MCF-7 was maintained in Dulbecco's Minimum Essential Medium (DMEM), while hormone dependent prostate carcinoma LNCaP was cultured in RPMI 1640 medium. Both media were supplemented with $10 \%$ heat-inactivated fetal calf serum, $1 \%$ L-glutamine, and $1 \%$ penicillin/ streptomycin. Cells of MCF-7 (10/well) and LNCaP $\left(10^{5} /\right.$ well) were cultivated in 96 well plates for 24 $\mathrm{h}$ before the Origanum essential oils were added. Essential oils were solubilized in DMSO then diluted in culture media for use. The essential oils dilutions (0 to $0.50 \mathrm{mg} / \mathrm{mL}$ ) were added to triplicate wells and cells incubated for further $24 \mathrm{~h}$. DMSO was tested as solvent control while doxorubicin was used as a reference standard. Cell viability was assessed by MTT assay and the percent inhibition of cell viability was calculated using cells treated with DMSO as control (Mosmann, 1983). The IC50 values (concentrations at which 50\% of cells were killed) were calculated from $\%$ inhibition of cell viability versus drug concentration graph.

\section{Statistical analysis}

All the experiments were conducted in three replicate and the data are presented as mean values \pm standard deviation of triplicate determinations. Statistical analysis of the data was performed by Analysis of Variance (ANOVA) using Statistica 5.5 (Stat Soft Inc, Tulsa, Ok, USA) software and a probability value of $p \leq 0.05$ was considered to represent a statistical significance difference among mean values.

\section{Results and Discussion}

The yields of the essential oils of $O$. majorana and $O$. vulgare were 17.2 and $22.0 \mathrm{~g} / \mathrm{kg}$, respectively (Table 1). It can be noted that Busatta et al. (2008) reported $1.20 \%$ essential oils yield from O. majorana. However, variations in the essential oils content and profiles within a single species growing in different geographical locations are not uncommon. In the Origanum oils, 43 compounds in all were identified (Table 1): a total of 39 individual compounds were identified from the essential oils of $O$. majorana (96.4\% of the total oil), and 43 were identified from the essential oils for $O$. vulgare $(92.9 \%$ of the total oil). The retention indices, percentage composition and identification methods are presented in Table 1, where the compositions are listed in order of elusion from HP-5MS column. The major components in $O$. majorana essential oils were identified as terpiene-4ol (20.9\%), linalool (15.7\%), limonene (13.4\%), linalyl acetate $(13.9 \%)$ and $\alpha$-terpineol $(10.8 \%)$, and the most abundant constituents $(>5 \%)$ in the essential oils of $O$. vulgare were found to be thymol $(21.6 \%)$, carvacrol (18.8\%), o-cymene (13.5\%) and $\alpha$-terpineol $(8.57 \%)$. Essential oils of these two Origanum species mainly consisted of oxygenated monoterpenes and monoterpene hydrocarbons. Terpiene-4-ol and thymol were the main oxygenated monoterpenes identified from the essential oils of $O$. majorana and $O$. vulgare, respectively. These findings were in good agreement with reports published previously (Vagi et al., 2005; Busatta et al., 2008), where the reported main constituent of $O$. majorana essential oils was terpinen-4-ol. The oils from $O$. vulgare, collected in Turkey, showed varied composition (Esen et al., 2007). According to Vagi et al. (2005), terpinen-4-ol was the main component of $O$. majorana essential oil, collected from Hungary, with contribution of $30.3 \%$.

The antibacterial activity of the essential oils of $O$. majorana and $O$. vulgare were assessed against a panel of human and plant pathogenic and food-borne bacterial strains. The essential oils exhibited antimicrobial activity against all bacterial strains tested (Table 2). In the disc diffusion assay as well as in the resazurin microtitre assay, the essential oils of $O$. majorana showed slightly better antimicrobial activity than that of $O$. vulgare with larger 
Table 1. Yield and composition of the essential oils of O. majorana and O. vulgare.

\begin{tabular}{|c|c|c|c|c|}
\hline \multirow{2}{*}{ Components $^{\mathrm{a}}$} & \multirow{2}{*}{$\mathrm{RI}^{\mathrm{b}}$} & \multicolumn{2}{|c|}{ Composition $(\%)^{\mathrm{c}}$} & \multirow{2}{*}{$\begin{array}{c}\text { Mode of } \\
\text { Identification }\end{array}$} \\
\hline & & O. vulgare & O. majorana & \\
\hline Monoterpene hydrocarbons & & 33.0 & 22.4 & \\
\hline$\alpha$-Pinene & 939 & $3.72 \pm 0.13$ & $0.96 \pm 0.08$ & RT, RI, MS \\
\hline Camphene & 954 & $0.74 \pm 0.06$ & $0.12 \pm 0.05$ & RT, RI, MS \\
\hline Sabinene & 968 & $0.30 \pm 0.02$ & --- & RI, MS \\
\hline$\beta$-Pinene & 979 & $0.53 \pm 0.02$ & $0.32 \pm 0.09$ & RT, RI, MS \\
\hline$\beta$-Myrecene & 991 & $0.39 \pm 0.03$ & $0.62 \pm 0.07$ & RT, RI, MS \\
\hline$\alpha$-Phellandrene & 999 & $0.10 \pm 0.01$ & $0.25 \pm 0.08$ & RT, RI, MS \\
\hline 2-Carene & 1003 & $2.05 \pm 0.10$ & $2.53 \pm 0.09$ & RI, MS \\
\hline$\alpha$-Terpinene & 1018 & $0.08 \pm 0.01$ & --- & RT, RI, MS \\
\hline$o$-Cymene & 1024 & $13.5 \pm 0.32$ & --- & RT, RI, MS \\
\hline$p$-Cymene & 1025 & $0.10 \pm 0.02$ & --- & RT, RI, MS \\
\hline Limonene & 1029 & $3.48 \pm 0.13$ & $13.4 \pm 0.44$ & RT, RI, MS \\
\hline$\beta$-Cymene & 1031 & $2.82 \pm 0.19$ & --- & RI, MS \\
\hline$\beta$-Phellandrene & 1032 & --- & $1.86 \pm 0.12$ & RT, RI, MS \\
\hline$\beta$-Ocimene & 1037 & $0.04 \pm 0.01$ & $0.03 \pm 0.01$ & RT, RI, MS \\
\hline$\gamma$-Terpinene & 1060 & $1.36 \pm 0.13$ & $1.42 \pm 0.05$ & RT, RI, MS \\
\hline$\alpha$-Terpinolene & 1089 & $1.76 \pm 0.13$ & $0.94 \pm 0.09$ & RT, RI, MS \\
\hline$\delta$-Terpinene & 1090 & $2.03 \pm 0.12$ & --- & RT, RI, MS \\
\hline Oxygenated monoterpenes & & 55.1 & 67.1 & \\
\hline 1,8-Cineol & 1031 & --- & $0.86 \pm 0.10$ & RT, RI, MS \\
\hline cis-Sabinene hydrate & 1070 & --- & $2.11 \pm 0.11$ & RI, MS \\
\hline$p$-Mentha-3,8-diene & 1072 & $0.29 \pm 0.08$ & --- & RI, MS \\
\hline Linalool oxide & 1088 & $0.02 \pm 0.01$ & --- & RI, MS \\
\hline Linalool & 1097 & $3.02 \pm 0.08$ & $15.7 \pm 0.45$ & RT, RI, MS \\
\hline Fenchyl alcohol & 1109 & $0.09 \pm 0.01$ & $0.10 \pm 0.02$ & RI, MS \\
\hline Isoborneol & 1146 & $0.38 \pm 0.03$ & --- & RI, MS \\
\hline Borneol & 1169 & $1.17 \pm 0.03$ & --- & RT, RI, MS \\
\hline Terpiene-4-ol & 1177 & $0.45 \pm 0.02$ & $20.9 \pm 0.40$ & RT, RI, MS \\
\hline$\alpha$-Terpineol & 1189 & $8.57 \pm 0.24$ & $10.8 \pm 0.50$ & RT, RI, MS \\
\hline Nerol & 1207 & $0.19 \pm 0.02$ & --- & RI, MS \\
\hline Piperitol & 1208 & --- & $0.48 \pm 0.02$ & RI, MS \\
\hline trans-Carveol & 1217 & --- & $0.38 \pm 0.03$ & RI, MS \\
\hline$\beta$-Citronellol & 1228 & $0.12 \pm 0.01$ & --- & RI, MS \\
\hline cis-Carveol & 1229 & --- & $1.61 \pm 0.03$ & RT, RI, MS \\
\hline Linalyl acetate & 1257 & --- & $13.9 \pm 0.30$ & RT, RI, MS \\
\hline Anethole & 1288 & $0.18 \pm 0.03$ & $0.25 \pm 0.08$ & RI, MS \\
\hline Thymol & 1290 & $21.6 \pm 0.84$ & --- & RT, RI, MS \\
\hline Carvacrol & 1328 & $18.8 \pm 0.42$ & --- & RT, RI, MS \\
\hline Geranyl acetate & 1380 & $0.20 \pm 0.02$ & $0.06 \pm 0.02$ & RI, MS \\
\hline Sesquiterpene hydrocarbons & & 2.34 & 6.63 & \\
\hline$\alpha$-Cubebene & 1340 & $0.38 \pm 0.03$ & $0.41 \pm 0.02$ & RI, MS \\
\hline Longicyclene & 1373 & $1.17 \pm 0.03$ & $0.15 \pm 0.03$ & RI, MS \\
\hline Copaene & 1377 & $0.05 \pm 0.01$ & $0.04 \pm 0.01$ & RI, MS \\
\hline$\beta$-Longipinene & 1398 & $0.04 \pm 0.01$ & $3.46 \pm 0.08$ & RI, MS \\
\hline
\end{tabular}


Table 1. (cont.)

\begin{tabular}{|c|c|c|c|c|}
\hline Longifolene & 1409 & $0.07 \pm 0.02$ & --- & RI, MS \\
\hline$\beta$-Caryophyllene & 1421 & $0.45 \pm 0.03$ & $1.64 \pm 0.03$ & RT, RI, MS \\
\hline Aromadendrene & 1430 & --- & $0.07 \pm 0.02$ & RI, MS \\
\hline$\alpha$-Humulene & 1450 & $0.08 \pm 0.02$ & $0.09 \pm 0.02$ & RI, MS \\
\hline$\beta$-Farnesene & 1458 & $0.02 \pm 0.01$ & $0.05 \pm 0.01$ & RI, MS \\
\hline Alloaromadendrene & 1461 & --- & $0.06 \pm 0.01$ & RI, MS \\
\hline$\alpha$-Selinene & 1470 & --- & $0.06 \pm 0.02$ & RI, MS \\
\hline ar-Curcumene & 1475 & $0.08 \pm 0.01$ & $0.03 \pm 0.01$ & RI, MS \\
\hline Germacrene D & 1480 & --- & $0.27 \pm 0.02$ & RI, MS \\
\hline Valencene & 1482 & --- & $0.18 \pm 0.02$ & RI, MS \\
\hline$\alpha$-Muurolene & 1499 & --- & $0.06 \pm 0.02$ & RI, MS \\
\hline$\alpha$-Farnesene & 1500 & --- & $0.06 \pm 0.01$ & RI, MS \\
\hline Oxygenated sesquiterpenes & & 2.50 & 0.19 & \\
\hline Caryophyllene oxide & 1583 & $0.21 \pm 0.02$ & $0.19 \pm 0.02$ & RT, RI, MS \\
\hline Spathulenol & 1586 & $0.14 \pm 0.02$ & --- & RI, MS \\
\hline Cadrol & 1596 & $1.04 \pm 0.04$ & --- & RI, MS \\
\hline$\alpha$-Cadinol & 1654 & $1.11 \pm 0.02$ & --- & RI, MS \\
\hline Total & & 92.9 & 96.4 & \\
\hline Yield $(\mathrm{g} / \mathrm{kg})$ & & $22.0 \pm 1.5$ & $17.2 \pm 0.90$ & \\
\hline
\end{tabular}

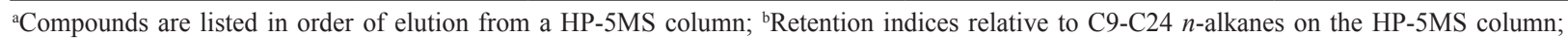
${ }^{c}$ Values are mean \pm standard deviation of three different samples of essential oils from each Origanum species, analyzed individually in triplicate. Mean followed by different superscript letters in the same row represent significant difference $(p<0.05)$. Compounds present in trace amounts $(<0.1 \%)$ were not registered; ${ }^{\mathrm{R} T}$, identification based on retention time; RI, Identification based on retention index; MS, identification based on comparison of mass spectra.

zones of inhibition (16.5-27.0 mm) and smaller MIC values (40.9-1250.3 $\mu \mathrm{g} / \mathrm{mL}$ ) against test bacterial strains. However, the antibacterial activity of the essential oils of O. vulgare was also good ( $>15 \mathrm{~mm}$ zones of inhibition) with the zones of inhibition within the range of 15.3-25.4 $\mathrm{mm}$ and the MIC values in the range of 70.0-2081.1 $\mu \mathrm{g} /$ $\mathrm{mL}$. Both essential oils were active, although at relatively high concentrations, against ampicillin-resistant E. coli. The greater resistance of Gram-negative bacteria to essential oils, as observed in this study (Table 2) might be owing to the great complexity of the double membranecontaining cell envelope of these bacterial in contrast to the single membrane structures of Gram-positive bacteria (Kalemba \& Kunicka, 2003; Bagamboula et al., 2004). Positive control, ciprofloxacin, showed much better activity than essential oils as expected. The findings of this study were in line with the antibacterial properties of several Origanum species reported previously (Bouchra et al., 2003; Bendahou et al., 2008; Ozcan \& Chalchat, 2009; Al-Kalaldeh et al., 2010; Eng \& Norman, 2010; Gonzalez \& Marioili, 2010). Essential oils of Origanum species generally contain monoterpenes, carvacrol, thymol, terpinene-4-ol and linalool. The biological activity of these oils is often attributed to the occurrence of such bioactive compounds (Soylu et al., 2006; Esen et al., 2007).

There are many methods reported in literature to evaluate the antimalarial activity of crude plant extracts (Kurosawa et al., 2000; Ncokazi \& Egan, 2005; Huy et al., 2006; Busatta et al., 2008). Almost all of them use live malaria parasites and or parasite extracts. Although the tests give an indication of the direct effects of the agents against the parasites, specialist care is needed to grow the parasites and the evaluation process may be costly and time consuming. On the other hand, the haem biocrystallisation assay is less costly and easy to perform. It is based on observation that during the intraerythrocytic development, malaria parasites degrade large amounts of hemoglobin within a specialized organelle, the digestive vacuole (Goldberg \& Slater, 1992) to supply amino acids for growth and development. A toxic by-product, ferriprotoporphyrin IX (FPIX), is produced during the catabolism of hemoglobin. The parasite detoxifies this FPIX through the formation of insoluble hemozoin crystals. Thus, agents that inhibit the conversion of FPIX to hemozoin may cause death from the lytic effects of haem or the haem drug complex may mediate parasite death (Egan \& Marques, 1999). Moreover, in vitro, hematin at acidic $\mathrm{pH}$, leads to $\beta$-hematin, a compound presumed to be identical to hemozoin. Hence, bioactive compounds or plant extracts able to inhibit the biocrystallization of hematin at this $\mathrm{pH}$, may possess antiplasmodial properties. This assay was employed to assess the potential 
Table 2. Antibacterial activity of $O$. majorana and $O$. vulgare essential oils ${ }^{\mathrm{a}}$

\begin{tabular}{|c|c|c|c|c|c|c|}
\hline \multirow[b]{2}{*}{ Bacterial strains } & \multicolumn{2}{|c|}{ O. majorana } & \multicolumn{2}{|c|}{ O. vulgare } & \multicolumn{2}{|c|}{ Ciprofloxacin } \\
\hline & $\begin{array}{c}\text { Zone of } \\
\text { inhibition } \\
\text { in } \mathrm{mm}^{\mathrm{b}}\end{array}$ & $\begin{array}{c}\mathrm{MIC} \\
(\mu \mathrm{g} / \mathrm{mL})^{\mathrm{c}}\end{array}$ & $\begin{array}{c}\text { Zone of } \\
\text { inhibition } \\
\text { in } \mathrm{mm}^{\mathrm{b}}\end{array}$ & $\begin{array}{c}\mathrm{MIC} \\
(\mu \mathrm{g} / \mathrm{mL})^{\mathrm{c}}\end{array}$ & $\begin{array}{l}\text { Zone of } \\
\text { inhibition } \\
\text { in } \mathrm{mm}^{\mathrm{b}}\end{array}$ & $\begin{array}{c}\mathrm{MIC} \\
(\mu \mathrm{g} / \mathrm{mL})^{\mathrm{c}}\end{array}$ \\
\hline $\begin{array}{l}\text { Staphylococcus aureus } \\
\text { (NCTC 6571) }\end{array}$ & $24.0 \pm 1.2$ & $80.6 \pm 3.4$ & $19.3 \pm 0.5$ & $210.3 \pm 9.4$ & $26.3 \pm 1.0$ & $15.6 \pm 0.2$ \\
\hline Bacillus cereus (NCTC 7464) & $24.3 \pm 1.2$ & $130.0 \pm 5.0$ & $24.5 \pm 0.9$ & $260.4 \pm 6.3$ & $34.0 \pm 1.6$ & $8.0 \pm 0.3$ \\
\hline Bacillus subtilis (NCTC 10400) & $27.0 \pm 1.3$ & $40.9 \pm 1.4$ & $25.4 \pm 1.1$ & $70.0 \pm 2.1$ & $32.1 \pm 1.0$ & $4.5 \pm 0.1$ \\
\hline Bacillus pumilis (wild type) & $16.5 \pm 0.5$ & $511.3 \pm 16.3$ & $19.6 \pm 0.9$ & $620.3 \pm 19.0$ & $22.6 \pm 1.0$ & $62.2 \pm 1.1$ \\
\hline $\begin{array}{l}\text { Pseudomonas aeruginosa } \\
\text { (NCTC 1662) }\end{array}$ & $19.5 \pm 0.6$ & $1250.3 \pm 36.0$ & $15.3 \pm 0.5$ & $2081.0 \pm 55.2$ & $30.1 \pm 1.8$ & $30.2 \pm 1.7$ \\
\hline $\begin{array}{l}\text { Salmonella Poona } \\
\text { (NCTC 4840) }\end{array}$ & $18.0 \pm 0.5$ & $1040.3 \pm 21.2$ & $20.5 \pm 0.7$ & $620.2 \pm 19.0$ & $24.7 \pm 1.1$ & $2.5 \pm 0.1$ \\
\hline Escherichia coli (ATCC 8739) & $19.5 \pm 0.9$ & $1250.0 \pm 33.0$ & $17.5 \pm 0.4$ & $1040.0 \pm 36.0$ & $31.0 \pm 1.7$ & $2.2 \pm 0.2$ \\
\hline $\begin{array}{l}\text { Ampicillin resistant Escherichia } \\
\text { coli (NCTC 10418) }\end{array}$ & $22.0 \pm 1.2$ & $830.9 \pm 26.6$ & $19.5 \pm 0.6$ & $1250.2 \pm 39.0$ & $33.0 \pm 1.5$ & $5.5 \pm 0.2$ \\
\hline
\end{tabular}

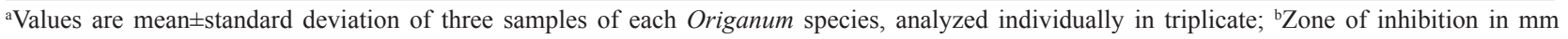
including the disc diameter $(6 \mathrm{~mm})$; ${ }^{\circ} \mathrm{MIC}$, minimal inhibitory concentration $\left(\mu \mathrm{g} \mathrm{mL}^{-1}\right)$.

antimalarial activity of the Origanum essential oils. Of the two Origanum essential oils tested, the $O$. vulgare essential oils showed anti-heme biocrystallization activity (Table 3). The $O$. vulgare essential oils at a concentration of $10 \mathrm{mg} / \mathrm{mL}$ exhibited $91.7 \%$ inhibition (IC50=0.04 $\mathrm{mg} / \mathrm{mL}$ ). However, O. majorana showed only $49.2 \%$ inhibition at the same concentration. The positive control chloroquine showed $90 \%$ inhibition at $0.005 \mathrm{mg} / \mathrm{mL}$. The ability of any compound to inhibit the biocrystallization of ferriprotoporphyrin IX (FPIX) is believed to be directly connected to their antimalarial activity (Raynes et al., 1996).

The antioxidant activity of Origanum essential oils was assessed by different in-vitro tests. In the DPPH assay, the radical scavenging capacity of the tested essential oils increased in a concentration dependent manner. The values for 50\% scavenging (IC50) are given in Table 3. The O. vulgare essential oils showed better radical scavenging activity (IC50: $65.5 \mu \mathrm{g} / \mathrm{mL}$ ) than that of O. majorana essential oil (IC50: $89.2 \mu \mathrm{g} / \mathrm{mL}$ ). However, the activity of both oils was less than that of the positive control, BHT (IC50: $9.9 \mu \mathrm{g} / \mathrm{mL}$ ), a well known free radical scavenger. Table 3 also shows the level of percent inhibition of linoleic acid oxidation as exhibited by the tested essential oils. Both $O$. vulgare and $O$. majorana essential oils depicted statistically similar inhibition, i.e., 77.3 and $72.8 \%$, respectively. The activity was slightly less than that of the positive control BHT (90.9\%). The antioxidant activity of the essential oils of $O$. vulgare and $O$. majorana was also assessed qualitatively by bleaching $\beta$-carotene in linoleic acid system assay. In this assay, the greater the effectiveness of an antioxidant, the slower will be the color depletion, and less decrease in absorbance indicates a lower rate of oxidation of linoleic acid reflecting higher antioxidant activity. The $O$. vulgare essential oil exhibited better antioxidant activity than $O$. majorana oil. The control showed the highest rate of color depletion and thus least antioxidant activity.

Lipid peroxidation is an important issue in food industries and while comparing the present findings with the literature, not even a single report showing the percent inhibition of peroxidation by Origanum essential oils could be found. However, there are some reports available in the recent literature on the radical scavenging activity of other Lamiaceae essential oils (Puertas-Mejiia et al., 2002; Ruberto et al., 2002; Hussain et al., 2008; Kelen \& Tepe, 2008; Hussain et al., 2010). The antioxidant activity of essential oils may be attributed to the presence of phenolic compounds as was observed in Salvia officinalis (Lu \& Foo, 2000). Singh \& Marimuthu (2006) found that essential oils effectively suppress the peroxide formation in linoleic acid system during incubation.

The MTT assay is a sensitive, simple and reliable method for evaluating cytotoxicity of plantbased products. The effect of increasing amounts of the tested Origanum essential oils on the cell proliferation of two human cancer (MCF-7 and LNCaP) and one fibroblast (NIH-3T3) cell lines was appraised. The inhibitory effect of Origanum essential oils on cancer cell viability ranged from $79-88 \%$ at $0.5 \mathrm{mg} / \mathrm{mL}$ (data not shown). The IC50 values, calculated from the graphs, are presented in Table 3, indicating that the tested 
Table 3. Antimalarial, antioxidant and cytotoxic activities of $O$. majorana and $O$. vulgare essential oils ${ }^{\mathrm{a}}$

\begin{tabular}{|c|c|c|c|c|c|c|c|}
\hline \multirow[b]{2}{*}{ Materials } & \multicolumn{2}{|c|}{ Heme biocyrstallization assay } & \multicolumn{2}{|c|}{ Antioxidant activity } & \multicolumn{3}{|c|}{ Cytotoxicity assay (IC50, $\mu \mathrm{g} / \mathrm{mL})$} \\
\hline & $\begin{array}{c}\text { Inhibition }(\%) \text { at } \\
10 \mathrm{mg} / \mathrm{mL}\end{array}$ & $(\mathrm{IC} 50, \mathrm{mg} / \mathrm{mL})$ & $\begin{array}{c}\text { DPPH, } \\
\text { IC50, } \\
(\mu \mathrm{g} \mathrm{mL}-1)\end{array}$ & $\begin{array}{c}\text { Inhibition of } \\
\text { linoleic acid } \\
\text { peroxidation }(\%)\end{array}$ & $\begin{array}{c}\text { Breast } \\
\text { cancer } \\
(\mathrm{MCF}-7)\end{array}$ & $\begin{array}{l}\text { Prostate } \\
\text { cancer } \\
(\mathrm{LNCaP})\end{array}$ & $\begin{array}{l}\text { Fibroblast } \\
\text { (NIH-3T3) }\end{array}$ \\
\hline $\begin{array}{l}\text { Origanum } \\
\text { majorana }\end{array}$ & $49.2 \pm 1.8$ & $>10.0$ & $89.2 \pm 2.4$ & $72.8 \pm 4.9$ & $70.0 \pm 2.5$ & $85.3 \pm 2.8$ & $300.5 \pm 12.0$ \\
\hline $\begin{array}{l}\text { Origanum } \\
\text { vulgare }\end{array}$ & $91.7 \pm 5.3$ & $0.04 \pm 0.01$ & $65.5 \pm 2.0$ & $77.3 \pm 3.5$ & $100.0 \pm 4.5$ & $90.1 \pm 3.2$ & $320.3 \pm 9.7$ \\
\hline $\begin{array}{l}\text { Chloroquine } \\
\text { diphosphate }\end{array}$ & $\begin{array}{c}90 \% \text { with } \\
0.005 \mathrm{mg} / \mathrm{mL}\end{array}$ & $<0.005$ & NT & NT & NT & NT & NT \\
\hline BHT & NT & NT & $9.9 \pm 0.2$ & $90.9 \pm 2.7$ & NT & NT & NT \\
\hline Doxorubicin & NT & NT & NT & NT & $28.8 \pm 1.2$ & $33.3 \pm 1.1$ & NT \\
\hline
\end{tabular}

${ }^{1}$ Values are mean \pm standard deviation of three samples of each Origanum species, analyzed individually in triplicate. NT=not tested.

Origanum essential oils showed prominent cytotoxicity against both the cancer cell lines. The cytotoxicity of O. majorana essential oil against MCF-7, LNCaP and NIH-3T3 cell lines in terms of IC50 values were $70.0,85.3$ and $300.5 \mu \mathrm{g} / \mathrm{mL}$, respectively, and were notably stronger than those of $O$. vulgare essential oil (Table 3). Doxorubicin was used as the positive control in the case of cytotoxicity test against MCF-7 and LNCaP cell lines, and the IC50 values were 28.8 and $33.3 \mu \mathrm{g} / \mathrm{mL}$, respectively. These essential oils were comparatively less toxic against fibroblast (NIH-3T3) cell line. The analysis of variance showed significant $(p<0.05)$ variation in the toxicity of both essential oils tested. Generally, it is believed that the major bioactive components of essential oils determine their biological properties. According to published guidelines, the IC $50<10 \mu \mathrm{g} / \mathrm{mL}$ represents potentially very toxic; IC50 $10-100 \mu \mathrm{g} / \mathrm{mL}$ represents potentially toxic; IC50 $100-1000 \mu \mathrm{g} / \mathrm{mL}$ represents potentially harmful and IC $50>1000 \mu \mathrm{g} / \mathrm{mL}$ represents potentially non toxic (Gad-Shayne, 1999). There are only a few reports in literature on the cytotoxicity of some Lamiaceae essential oils (Sivropoulou et al., 1996; Sivropoulou et al., 1997; Legault et al., 2003; DeSousa et al., 2004).

Finally, the composition and profile of the essential oils of $O$. majorana and $O$. vulgare as observed in the present study were comparable but not exactly the same with other published data. The bioassay results demonstrated that the essential oils of both $O$. majorana and $O$. vulgare had antioxidant, antibacterial and cytotoxic potentials. However, only $O$. vulgare essential oils exhibited potential antimalarial activity.

\section{Acknowledgements}

Grants supports by the Higher Education Commission, Islamabad, Pakistan under the
International Research Initiative Support Program and the Indigenous PhD Fellowship Program schemes are gratefully acknowledged.

\section{References}

Adams RP 2004. Identification of essential oil component by gas chromatography/quadrupole mass spectroscopy. Illinois: Allured Publishing Corporation.

Al-Kalaldeh JZ, Abu-Dahab R, Afifi FU 2010. Volatile oil composition and antiproliferative activity of Laurus nobilis, Origanum syriacum, Origanum vulgare, and Salvia triloba against human breast adenocarcinoma cells. Nutr Res 30: 271-278.

Anwar F, Ali M, Hussain AI, Shahid M 2009. Antioxidant and antimicrobial activities of essential oil and extracts of fennel (Foeniculun vulgare Mill.) seeds from Pakistan. Flavour Frag J 24: 170-176.

Baelmans R, Deharo E, Bourdy G, Munõz V, Quenevo C, Sauvaind M, Ginsburg H 2000. A search for natural bioactive compounds in Bolivia through a multidisciplinary approach Part IV. Is a new haem polymerisation inhibition test pertinent for the detection of antimalarial natural products? $J$ Ethnopharmacol 73: 271-275.

Bagamboula CF, Uyttendaele M, Debevere J 2004. Inhibitory effect of thyme and basil essential oils, carvacrol, thymol, estragol, linalool and p-cymene towards Shigella sonnei and Shigella flexneri. Food Microbiol 21: 33-42.

Bendahou M, Muselli A, Grignon-Dubois M, Benyoucef M, Desjobert JM, Bernardini AF, Costa J 2008. Antimicrobial activity and chemical composition of Origanum glandulosum Desf. essential oil and extract obtained by microwave extraction: comparison with hydrodistillation. Food Chem 106: 132-139.

Bouchra C, Achouri M, Hassani LMI, Hmamouchi M 2003. Chemical composition and antifungal activity of essential oils of seven Moroccan Labiatae against Botrytis cinerea Pers. Fr. J Ethnopharmacol 89: 165 - 
169.

Busatta C, Vidal RS, Popiolski AS, Mossi AJ, Dariva C, Rodrigues MRA, Corazza FC, Corazza MI, Oliveira JV, Cansian RI 2008. Application of Origanum majorana L. essential oil as an antimicrobial agent in sausage. Food Microbiol 25: 207-211.

Daferera DJ, Ziogas BN, Polissiou MG 2000. GC/MS analysis of essential oils from Greek aromatic plants and their fungitoxicity on Penicillum digitatum. J Agr Food Chem 48: 2576-2581.

De Sousa AC, Alviano DS, Blank AF, Alves PB, Alviano CS, Gattass CR 2004. Melissa officinalis L. essential oil: antitumoral and antioxidant activities. J Pharm Pharmacol 56: 677-681.

Egan TJ, Marques HM 1999. The role of haem in the activity of chloroquine and related antimalarial drugs. Coordin Chem Rev 192: 493-517.

Eng W, Norman R 2010. Development of an oregano-based ointment with anti-microbial activity including activity against methicillin-resistant Staphlococcus aureus. J Drugs Dermatol 9: 377-380.

Esen G, Azaz AD, Kurkcuoglu M, Baser KHC, Tinmaz A 2007. Essential oil and antimicrobial activity of wild and cultivated Origanum vulgare L. subsp. Hirtum (Link) letswaart from the Marmara region, Turkey. Flavour Frag J 22: 371-376.

Fitch CD, Cai GZ, Chen YF, Shoemaker JD 1999. Involvement of lipids in ferriprotoporphyrin IX polymerization in malaria. Biochim Biophys Acta 1454: 31-37.

Gad-Shayne C 1999. Alternatives to in vivo studies in toxicology. In Balantyne B, Marrs T, Syversen T (eds) General and applied toxicology. Vol 1. USA: Grove's Dictionari's Inc., p. 178.

Goldberg DE, Slater A 1992. The pathway of haemoglobin degradation in malaria. Parasitol Today 8: 280-283.

Gonzalez MJ, Marioli JM 2010. Antibacterial activity of water extracts and essential oils of various aromatic plants against Paenibacillus larvae, the causative agent of American foulbrood. J Invertebr Pathol 104: 209-213.

GRIN Taxonomy Database 2010. USDA, ARS, National Genetic Resources. http://www.ars-grin.gov/cgi-bin/ npgs/html/tax_search.pl, accessed in June 2010.

Huy NT, Uyen DT, Sasai M, Trang DT, Shiono T, Harada S, Kamei K 2006. A simple and rapid colorimetric method to measure hemozoin crystal growth in vitro. Anal Biochem 354: 305-307.

Hussain AI, Anwar F, Sherazi STH, Przybylski R 2008. Chemical composition, antioxidant and antimicrobial activities of basil (Ocimum basilicum) essential oils depend on seasonal variations. Food Chem 108: 986995.

Hussain AI, Anwar F, Shahid M, Ashraf M, Przybylski R 2010. Chemical composition, antioxidant and antimicrobial activities of essential oil of spearmint (Mentha spicata L.) from Pakistan. J Essent Oil Res 22: 78-84.

Kalemba D, Kunicka A. 2003. Antibacterial and antifungal properties of essential oils. Curr Med Chem 10: 813829.

Kelen M, Tepe B 2008. Chemical composition, antioxidant and antimicrobial properties of the essential oils of three Salvia species from Turkey flora. Bioresource Technol 99: 4096-4104.

Kurosawa Y, Dorn, A, Kitsuji-Shirane M, Shimada H, Satoh T, Matile H, Hofheinz W, Masciadri R, Kansy M, Ridley RG 2000. Hematin polymerization assay as a high-throughput screen for identification of new antimalarial pharmacophores. Antimicrob Agents Chem 44: 2638-2644.

Legault J, Dahl W, Debition E, Pichette A, Maldemont JC 2003. Antitumor activity of balsam fir oil: production of reactive oxygen species induced by $\alpha$-Humulene as possible mechanism of action. Planta Med 69: 402407.

Lu F, Foo LY 2001. Antioxidant activities of polyphenols from sage (Salvia officinalis). Food Chem 75: 197202.

Massada Y 1976. Analysis of essential oils by gas chromatography and mass spectrometry. New York: John Wiley \& Sons.

Mimica-Dukic N, Bozin B, Sokovic M, Mihajlovic B, Matavulj M 2003. Antimicrobial and antioxidant activities of three Mentha species essential oils. Planta Med 69: 413-419.

Mosmann T 1983. Rapid colorimetric assay for cellular growth and survival - application to proliferation and cytotoxicity assays. J Immunol Methods 65: 55-63.

Ncokazi KK, Egan TJ 2005. A colorimetric high-throughput betahematin inhibition screening assay for use in the search for antimalarial compounds. Anal Biochem 338: 306-319.

Ozcan MM, Chalchat JC 2009. Chemical composition and antimicrobial properties of the essential oil of Orgiganum saccatum L. J Food Safety 29: 617-628.

Puertas-Mejia M, Hillebrand S, Stashenko E, Winterhalter P 2002. In vitro radical scavenging activity of essential oils of Columbian plants and fractions from oregano (Origanum vulgare L) essential oil. Flavour Frag $J$ 17: 380-384.

Raynes K, Foley M, Tilley L, Deady LW 1996. Novel bisquinoline antimalarials - synthesis, antimalarial activity, and inhibition of haem polymerization. Biochem Pharmacol 52: 551-559.

Ruberto G, Barrata MT, Sari M, Kaabexhe M 2002. Chemical composition and antioxidant activity of essential oils from Algerian Origanum glandulosum Desf. Flavour Frag J 17: 251-254.

Sarker SD, Nahar L, Kumarasamy Y 2007. Microtitre platebased antibacterial assay incorporating resazurin as an indicator of cell growth, and its application in the in vitro antibacterial screening of phytochemicals. Methods 42: 321-324.

Singh G, Marimuthu P 2006. Antioxidant and biocidal activities of Carum nigrum (seed) essential oil, oleoresin, and their selected components. J Agr Food Chem 54: 174-181.

Sivropoulou A, Nikolaou C, Papanikolaou E, Kokkini S, Lanaras T, Arsenakis M 1997. Antimicrobial, cytotoxic, and antiviral activities of Salvia fruticosa essential oil. J Agr Food Chem 45: 3197-3201.

Sivropoulou A, Papanikolaou E, Nikolaou C, Kokkini S, Lanaras T, Arsenakis M 1996. Antimicrobial and 
cytotoxic activities of Origanum essential oils. $J \mathrm{Agr}$ Food Chem 44: 1202-1205.

Soylu EM, Soylu S, Kurt S 2006. Antimicrobial activity of the essential oils of various plants against tomato late blight disease agent Phytophthora infestans. Mycopathologia 161: 119-128.

Tripathi AK, Khan SI, Walker LA, Tekwani BL 2004. Spectrophotometric determination of the novo hemozoin/ $\beta$-hematin formation in an in vitro assay. Anal Biochem 325: 85-91.

Vagi E, Simandi B, Suhajda A, Hethelyi E 2005. Essential oil composition and antimicrobial activity of Origanum majorana L. extracts obtained with ethyl alcohol and supercritical carbon dioxide. Food Res Int 38: 51-57.
Vagionas K, Graikou K, Ngassapa O, Runyoro D, Chinou I 2007. Composition and antimicrobial activity of the essential oils of three Satureja species growing in Tanzania. Food Chem 103: 319-324.

\section{*Correspondence}

Satyajit D. Sarker

Department of Pharmacy, School of Applied Sciences, University of Wolverhampton

MM Building, Molineux Street, Wolverhampton WV1 1SB, West Midland, UK

s.sarker@wlv.ac.uk

Tel.: +4401902322578 